\title{
Ban Ki-moon Urges Leaders to Ensure that Indigenous Peoples' Rights and Cultural Contributions Remain Central in Combating Climate Change
}

\author{
Øyvind Ravna, \\ Professor, Faculty of Law, UiT - The Arctic University of Norway, Trosmø, Norway; \\ Editor-in-chief, Arctic Review on Law and Politics
}

On 8 October 2016, UN Secretary-General Ban Ki-moon received the Arctic Circle Prize 2016 for his leadership in bringing together world leaders for the Paris climate agreement. The Secretary-General gave an impressive acceptance speech at the Arctic Circle Assembly in Reykjavik, which addressed the challenges facing the global community created by rapidly increasing climate change. That he urged political leaders on all levels to increase their efforts to prevent climate change, and do everything in their power to stay within the two-degree aim, was not so surprising. What was more surprising was that he spent a considerable portion of the roughly 20-minute speech highlighting the importance of the traditional knowledge of indigenous peoples in fighting climate change. That he did so was particularly pleasing for those of us who work with indigenous peoples' rights and issues.

The Secretary-General introduced the subject of indigenous peoples' knowledge by urging the 2,000 delegates at the Arctic Circle Assembly to remember the many indigenous peoples who are on the front lines when it comes to facing climate change. Here is what the Secretary-General said:

What happens in the Arctic affects us all. But let us remember those on the front lines, the many indigenous peoples who have lived here for centuries. They contribute to the Arctic's diversity and sustainable resource management. Yet, as with the developing countries, those who have contributed least to climate change, they are hit first and hardest by serious consequences for their safety, health and human rights.

Indigenous peoples are also affected by national strategies for climate change adaptation, especially renewable energy initiatives such as windmill farms and hydropower projects, which often take place in their territories. This has created tension and brought displacement and dispossession. 
Secretary-General Ban Ki-moon emphasised the UN Declaration on the Rights of Indigenous Peoples as the UN and global community's inspiration for how to recognise and respect indigenous peoples through actions and initiatives. He went on to stress the importance of indigenous peoples' traditional knowledge in helping to achieve the sustainable development goals and combat climate change, before concluding:

We have often seen many specialist, governmental and industrial policies in the name of economical development have been fighting against nature. Indigenous people have centuries of old wisdom of living in harmony with nature. We have to learn these wisdoms from them. I urge you to ensure that indigenous peoples, their rights and their cultural contributions remain central as we address these challenges. 